
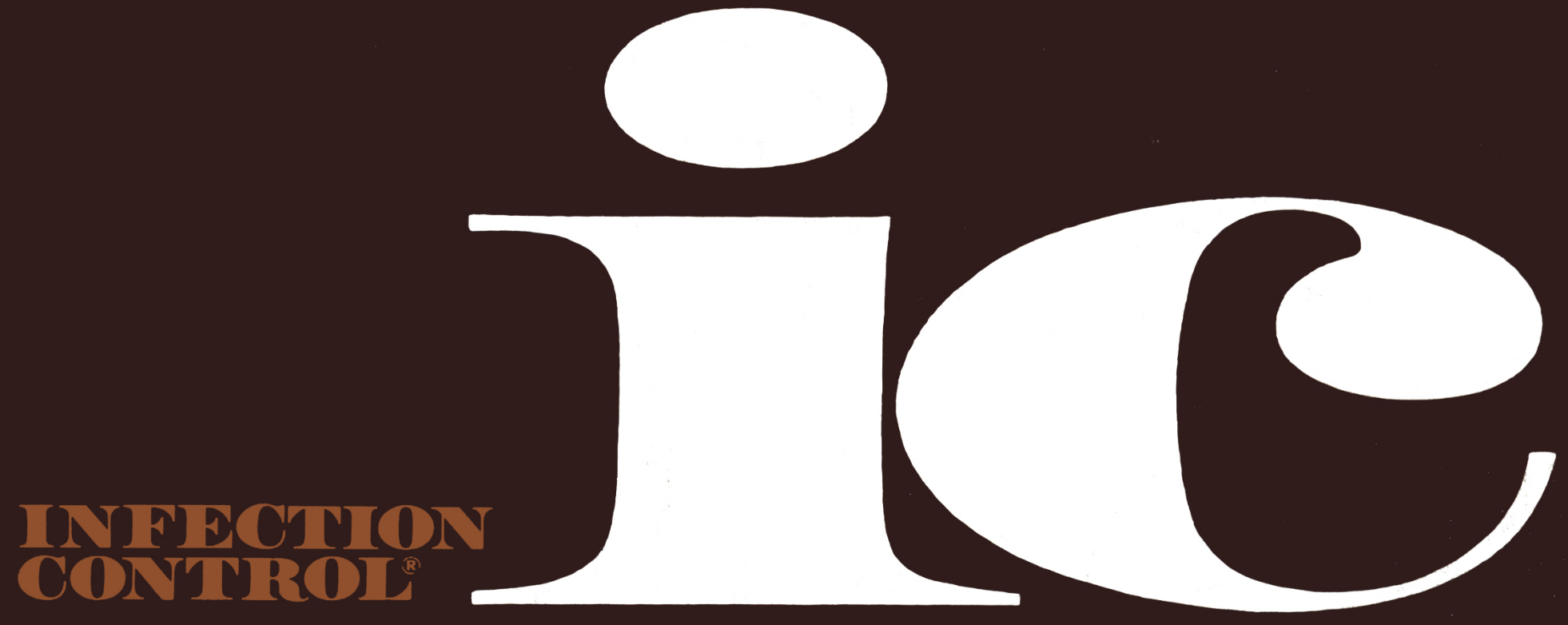

September/October 1982

Volume 3/Number 5

Editorial Series

Original Articles
Hepatitis B Vaccine

Richard A. Garibaldi, M.D.; Bruce H. Hamory, M.D.;

Peter N.R. Heseltine, M.D.; and

Edward J. Septimus, M.D., F.A.C.P.

Increasing Occurrence of Methicillin-Resistant

Staphylococcus aureus in the United States

John M. Boyce, M.D. and William A. Causey, M.D.

Quantitative Antibiogram as a Potential Tool for Epidemiological Typing

D.J. Flournoy, Ph.D.

Presumed Autoclave Failure Due to

False-Positive Spore Strip Tests

Inge Gurevich, R.N., M.A.; Joyce E. Holmes, M.T.;

and Burke A. Cunha, M.D.

Comparison of Broth and Filtration Methods for Culturing of Intravenous Fluids

Jenice N. Longfield, M.D., M.P.H.; Patricia Charache, M.D.;

Earl L. Diamond, Ph.D.; and Timothy R. Townsend, M.D.

Recommend Precautions for Patients with Legionnaires' Disease

William R. Jarvis, M.D. 


\section{The Untouchable.}

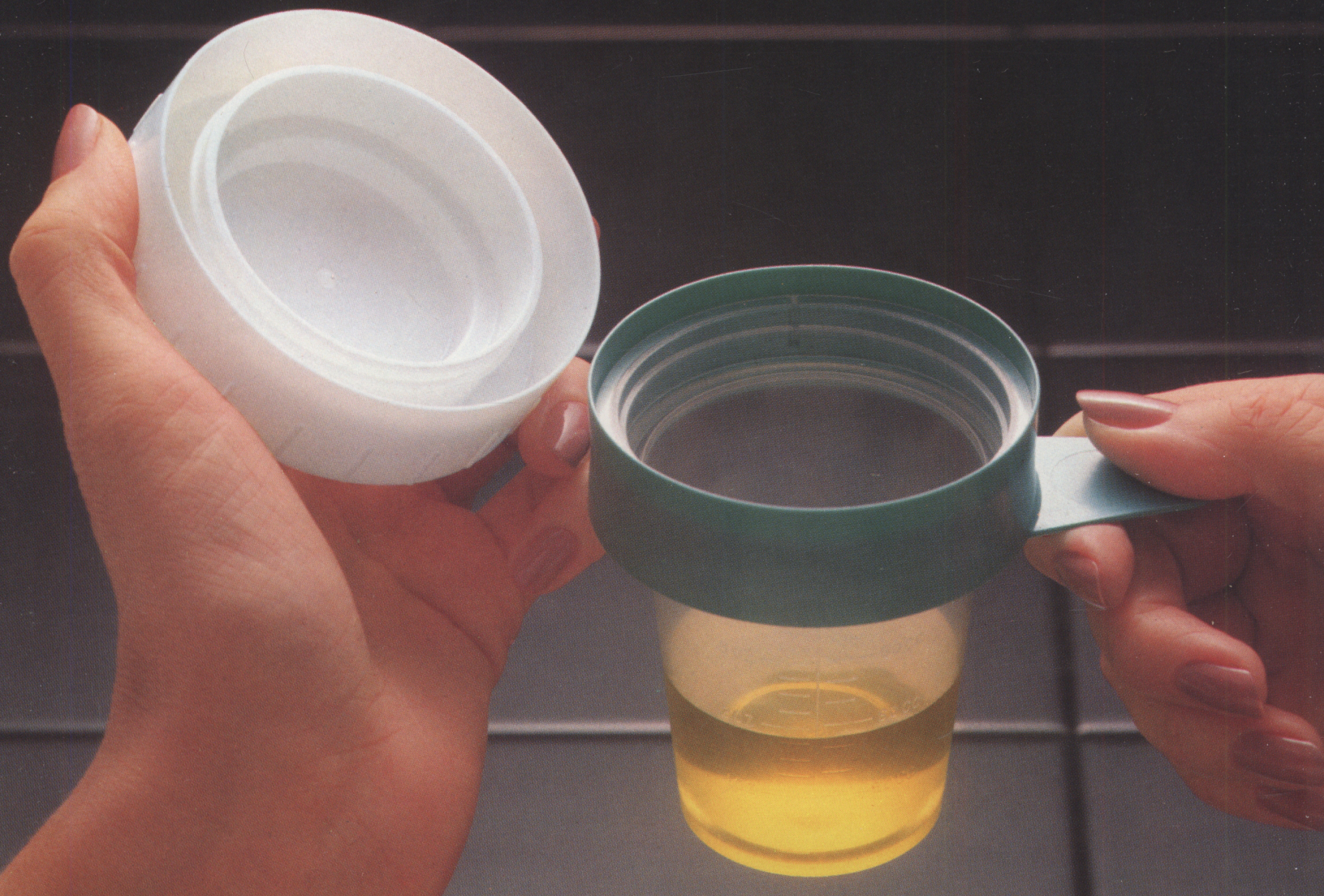




\section{Introducing \\ Asepti-Catch: \\ Designed to be \\ more patient-proof \\ than any other \\ midstream \\ specimen set.}

You know what it's like...

The fumbling, bumbling, balancing act...The grappling with lids and containers that so many patients go through when they try to collect a midstream urine specimen.

And the result - too often, samples contaminated by everything from unsterile surfaces to their own bodies.

Our new Asepti-Catch reduces those problems with an easy-use design so fumble-free, it's practically patient-proof.

Look how easily it works.
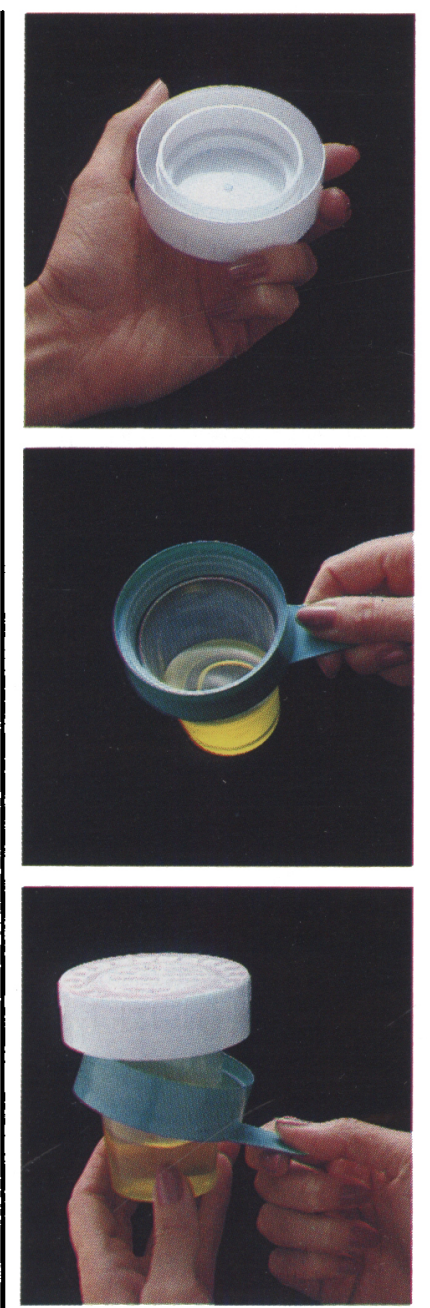

1. This self-contained, recessed cap means you can set the cap down either side up with reduced chance of contamination of sterile surfaces. This unique patented* design also helps to reduce patient touch contamination of the sterile inner surface of the cap.

And unlike other midstream sets, there's no need for a protective cover on the cap that requires patient manipulation. 2. An innovative bandle for ease of use is attached to a patented protective collar design that keeps the container rim recessed and clean during the entire collection procedure.

3. The bandle and protective collar can be easily removed by simply pushing downward on the handle after the cap is placed on the container.

rreen pending
Each Asepti-Catch comes with three cleansing towelettes, simple directions and a patient label already affixed to the cap.

Asepti-Catch. The untouchable one. Your patients couldn't handle anything easier.

For a free sample, just contact your American Pharmaseal representative. Or write to American Pharmaseal, Nursing Products Division, P.0. Box 1300, Glendale, CA 91209. 


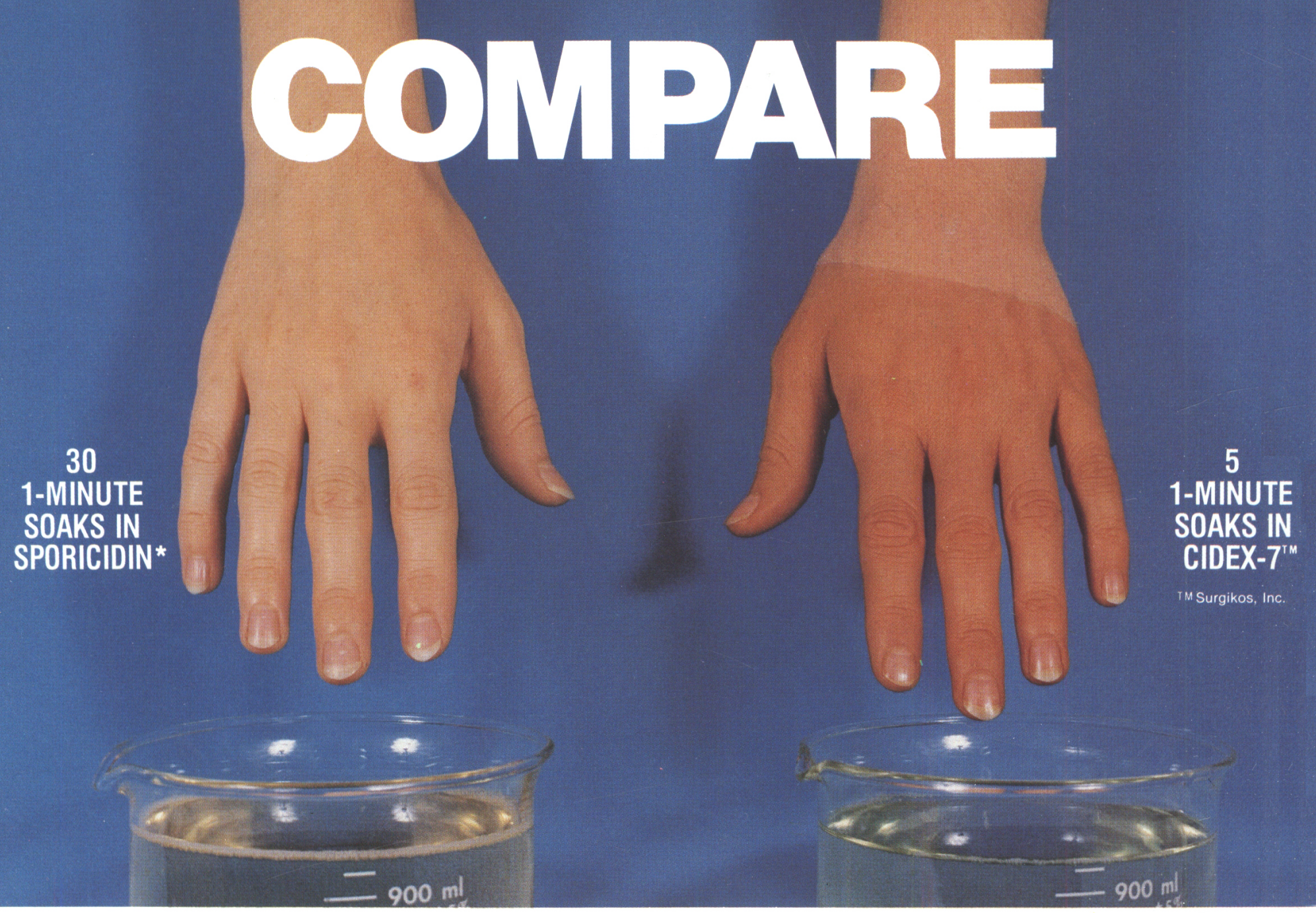

\section{Dip test for illustration purposes only. Aseptic technique is recommended.

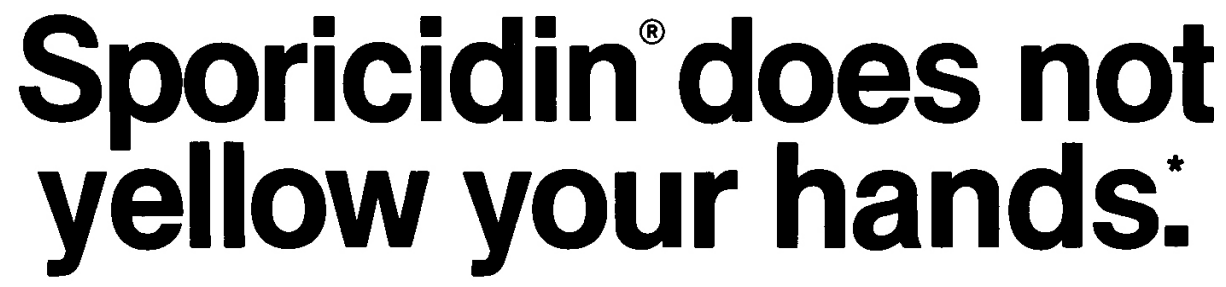

HEPATITIS

A C.D.C. study

indicates that a 1:16 dilution of Sporicidin is effective against the hepatitis $B$ virus

in 10 minutes.

Abstracts of the annual meeting of The America
Society for Microbiology. P. 233. March 1982 Societry for Microbiology, P., 233 , March 1982
ICenters tor Disease Control, Phoenix, Arizor

\section{Advantages of Sporicidin diluted for disinfection:}

No gloves are necessary... Doesn't stain or irritate the hands. Also, it will not "smart" the eyes or nostrils.

Most effective... The only sterilizing solution which is fully effective against the tubercle bacillus, influenza and enteroviruses when diluted 1 in 16.

Stable. . . A fully effective sterilant and disinfectant for 30 days after activation.

Equipment safe... Will not harm rubber or plastics. Safe for Scopes.

Saves money 3 ways... An 8 oz. unit makes up to 2 gallons of hospital disinfectant. It reduces disinfection costs, shipping charges, and saves up to $97 \%$ storage space. * Diluted 1 in 16 for disinfection. (Other glutaraldehyde
products must be used full strength only.)

\section{Proven. . . The most effective cold sterilant and disinfectant ever registered by the E.P.A.}

"Sporicidin is (a) the fastest glutaraldehyde sterilant at room temperature, and (b) the only glutaraldehyde product that can be diluted below $2 \%$ and still qualify as a hospital disinfectant."

Intection Control, 2(1): 26-30, 1981

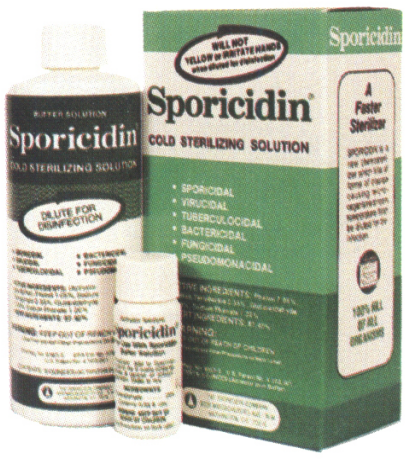

"Sporicidin. . .was both more stable and more active against test spores than. . Cidex and Cidex-7."

Infection Control, 1(2): 90-93, 1980

"This study has determined that although E.P.A. requirements for classifying a sterilizing agent were satisfied by Cidex, they were exceeded by Sporicidin."

Journal of Dental Research, Vol. 60, March 1981 


\section{Editorial Series}

Hepatitis B Vaccine

Richard A. Garibaldi, M.D.; Bruce H. Hamory, M.D.;

Peter N.R. Heseltine, M.D.; and Edward J. Septimus, M.D., F.A.C.P.

\section{Original Articles}

Increasing Occurrence of Methicillin-Resistant Staphylococcus aureus

in the United States

John M. Boyce, M.D. and William A. Causey, M.D.

Quantitative Antibiogram as a Potential Tool for Epidemiological Typing

D.J. Flournoy, Ph.D.

Presumed Autoclave Failure Due to False-Positive Spore Strip Tests

Inge Gurevich, R.N., M.A.; Joyce E. Holmes, M.T.; and Burke A. Cunha, M.D.

Comparison of Broth and Filtration Methods for Culturing

of Intravenous Fluids

Jenice N. Longfield, M.D., M.P.H.; Patricia Charache, M.D.;

Earl L. Diamond, Ph.D.; and Timothy R. Townsend, M.D.

Recommended Precautions for Patients with Legionnaires' Disease

William R. Jarvis, M.D.

\section{Departments}

Letters to the Editor

Information for Authors

Topics in Clinical

Microbiology

Readers' Forum

Book Reviews

New Developments
New Products and

Services

Legislative News

Hepatitis B Vaccine

Directive

435

436

The ideas and opinions expressed by contributing authors do not necessarily reflect those of the editors or publisher.

Publisher: Infection Control is published bimonthly by Charles B. Slack, Inc., 6900 Grove Road, Thorofare, New Jersey 08086. Telephones: Thorofare (609) 848-1000; New York (212) 285-9777.

Copyright 1982: All rights reserved. No part of this publication may be reproduced without written permission from the publisher.

Subscriptions: Subscription requests should be addressed to the publisher. Annual subscription price is: Individual:One year$\$ 26.00$; Two years $-\$ 42.00$, Three years $-\$ 58.00$. Student rates: $\$ 13.00$ per year. All subscriptions, without exception, will start with the first issue published after the order is received. Back copies are available, but must be purchased separately. Cost per individual copy is $\$ 5.00$. Foreign subscribers add $\$ 10.00$ to regular rate; foreign orders, $\$ 6.00$.

Change of address: Notice should be sent to the publisher six weeks in advance of effective date. Include old and new addresses with zip codes. The publisher cannot accept responsibility for undelivered copies. Second-class postage is paid at Thorofare, New Jersey 08086. Publisher requests Form 3547 for address correction changes.

As of Volume 1, Number 1, INFECTION CONTROL is listed in Index Medicus, Current Contents-Clinical Practice, Hospital Literature Index, and Cumulative Index to Nursing and Allied Health Literature. 


\section{THE PRE-OP SHOWER OF PROTECTION}

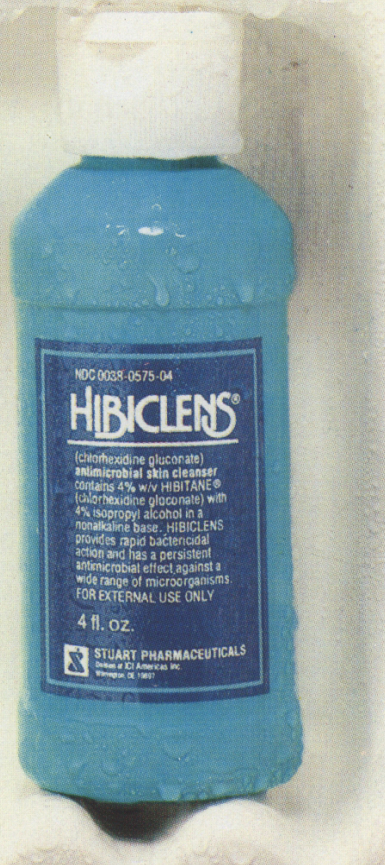

Preoperative total body cleansing with HIBICLENS reduces postoperative infection by half*

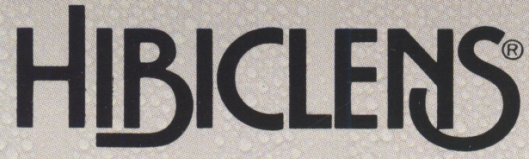

(chlorhexidine gluconate)
The Only Proven Antiseptic/Antimicrobial Skin Cleanser
In a comparative clinical trial, the superiority of HIBICLENS over routine cleansing procedures was proven.

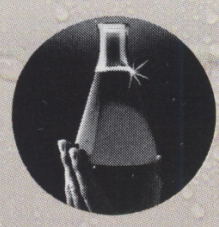
site as well as other areas of the patient's body-potential sources of postoperative wound infection. 


\section{EDITOR}

Richard P. Wenzel, MD

Charlottesville, Virginia

\section{SENIOR ASSOCIATE EDITOR}

William Schaffner, MD

Nashville, Tennessee

\section{EDITORIAL ADVISORY BOARD}

Robert C. Aber, MD

Hershey, Pennsylvania

Charles S. Bryan, MD

Columbia, South Carolina

John P. Burke, MD

Salt Lake City, Utah

Richard E. Dixon, MD

Trenton, New Jersey

Harvey A. Elder, MD

Loma Linda, California

Peter C. Fuchs, MD, PhD

Portland, Oregon

Richard A. Garibaldi, MD

Farmington, Connecticut

Donald A. Goldmann, MD

Boston, Massachusetts

Dieter H.M. Gröschel, MD

Charlottesville, Virginia

Peter A. Gross, MD

Hackensack, New Jersey

Karen Hadley, RN, MPH

New Orleans, Louisiana

Cyrus C. Hopkins, MD

Boston, Massachusetts

Allen B. Kaiser, MD

Nashville, Tennessee

Harold Laufman, MD, PhD

Bronx, New York

William J. Ledger, MD

New York, New York

Barbara McArthur, RN, BSN, MS, PhD

Detroit, Michigan
Rob Roy MacGregor, MD

Philadelphia, Pennsylvania

C. Glen Mayhall, MD

Richmond, Virginia

Ronald Lee Nichols, MD

New Orleans, Louisiana

Harry C. Nottebart, Jr., JD, MD

Richmond, Virginia

Karen Paul, BS, MS

Tacoma, Washington

Frank S. Rhame, MD

Minneapolis, Minnesota

William E. Scheckler, MD

Madison, Wisconsin

Robert J. Shannon, MSPH

Boston, Massachusetts

Walter E. Stamm, MD

Seattle, Washington

Charles W. Stratton, MD

Nashville, Tennessee

Timothy R. Townsend, MD

Baltimore, Maryland

William M. Valenti, MD

Rochester, New York

James Veazey, MD

Albany, New York

Kathy J. Wydra, RN

Rochester, New York

\author{
ASSOCIATE EDITORS \\ Sue Crow, RN, BS, MSN \\ Shreveport, Louisiana \\ John E. McGowan, Jr., MD \\ Atlanta, Georgia \\ Dennis G. Maki, MD \\ Madison, Wisconsin
}

\section{FOREIGN ADVISORY BOARD}

Graham Ayliffe, MD, FRC Path.

Birmingham, England

Professor G. Berencsi

Szeged, Hungary

Professor Jaap Dankert

Groningen, Netherlands

Professor Dr. F. Daschner

Freiburg, Wesı Germany

Lars $O$. Kallings, MD

Storkholm, Sweden

Professor W.B. Kedzia

Sierora, Poland

Professor A.P. Krasilnikow

Minsk, USSR

Professor Dr. W. Marget

Munich, West Germany

Bertil Nystrom, MD

Huddinge, Sweden

Ian Phillips, MA, MD, MRC Path, MRCP

London, England

Hans Reber, MD

Basel, Switzerland

Professor Gerald Reybrouck

Leuven, Belgium

Manfred L. Rotter, MD, DipBact

Vienna, Austria

Theodore Sacks, MD

Jerusalem, Israel

Professor Dr. med. H.P. Werner

Mainz, West Germany

Professor Dr. W. Weuffen

Griefswald, German Demorratic Republic

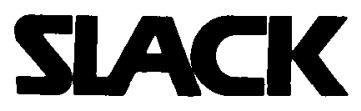

Charles B. Slack, Inc. 6900 Grove Road Thorofare, New Jersey 08086
Managing Editor

Donna Carpenter

Consulting Editor Eric Baloff

Associate Publisher

Richard N. Roash
Assistant Editor

John C. Carter

Editorial Assistants

Jody Zackon, Supervisor

Janice Rodan
Promotion Manager

Peter N. Slack

Circulation Manager

Betty J. Sheldon

Advertising Sales Representative Linda Nelson 


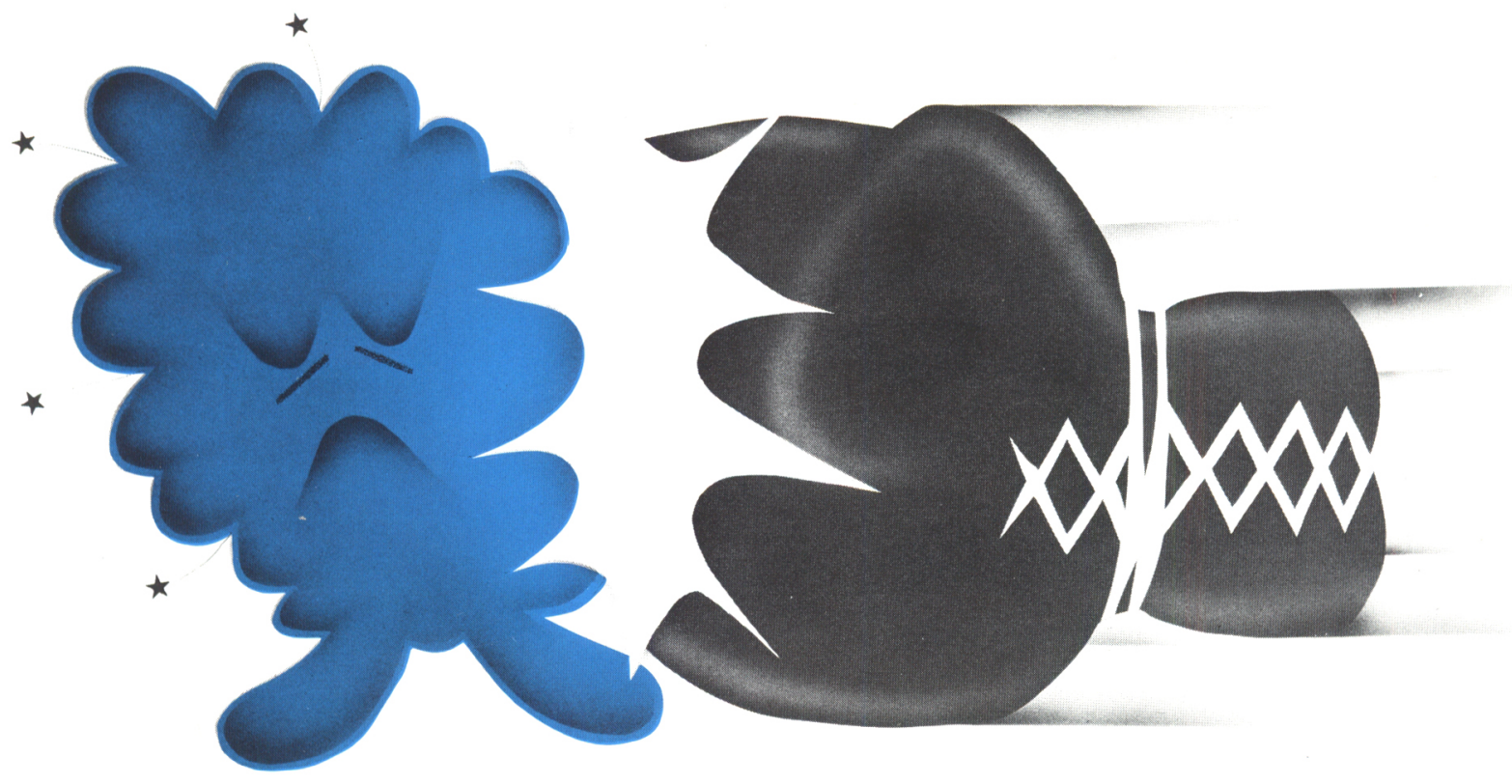

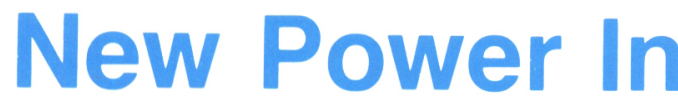
Your Fight Against

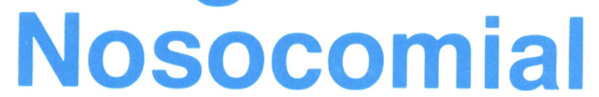

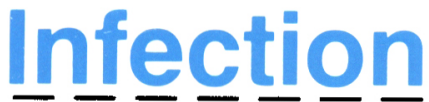

YES! I want to know more about BAC-DATA's infection control services. Please send me information on:

$\square$ Antibiotic Utilization Auditing $(A \cup A)$

$\square$ Infection Alert Reports (IAR)

$\square$ Bacteriologic Monitoring System (BMS)

Please have a BAC-DATA representative contact me.

Name

Title

Institution

Address

City/State/Zip

Phone

No. of Beds

Stop by Booth \#305 at the APIC in New Orleans and register for the drawing of valuable prizes!

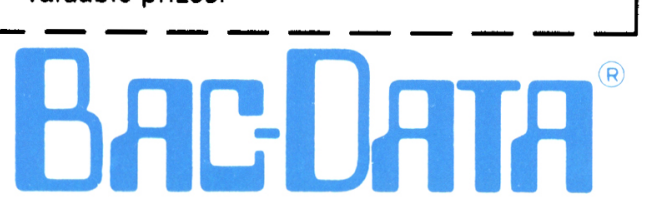

Bac-Data's new, improved Infection Control Services are a powerful supplement to your hospital's infection surveillance program.

We provide you with detailed reports which allow you to track nosocomial trends for the most current three months. These reports are flexible and can be tailored to fit your reporting criteria - service, nursing unit, diagnosis, physician, predisposing factor ... or several additional options. If you decide. to change your reports at any time, we can readily accommodate your request. You always maintain control of the analysis of your surveillance data.

Bac-Data's Infection Control Services:

- Provide a series of concise reports designed especially for infection control committee meetings.

- Show your nosocomial experience for the past three months. You see nosocomial trends, not just current information.

- Simplify collection and interpretation of surveillance findings.

- Provide valuable documentation in the event of malpractice litigation.

- Help you comply with JCAH recommendations.

Put our Infection Control Services in your corner to help win the fight against nosocomial infection. Our NO RISK, TRIAL PROGRAM lets you use and evaluate our services fully before making a decision to order.

Call Bac-Data now . . . collect . . . at (201) 790-6400 or send the coupon to Bac-Data Medical Information Systems, Inc., Campus Road, Totowa, N.J. 07512. 